\title{
EVALUATION OF DRAINAGE WATER QUALITY TO BE REUSED FOR IRRIGATION PURPOSES IN RIYADH AREA, SAUDI ARABIA
}

\author{
Ahmed A. Al-Othman
}

\section{$\underline{\text { ABSTRACT }}$}

Recent urban development tremendously increased the use of water in domestic, industrial and landscape irrigation which increased manifold production of wastewater of marginal quality. Saudi Arabia is an arid country having limited and non-renewable groundwater resources coupled with un-predictable and scanty rainfall. The growing demand of good quality water for various purposes has forced the water planners to find an alternate sources of water to lower burden on freshwater groundwater resources. In Riyadh city, about one million cubic meter of wastewater is flowing daily in Wadi Hanifah. To explore the quality of that water and its effect, a study was carried out along the main drainage channel known as "Wadi Hanifah Stream" often called as man-maderiver to examine its quality including chemical composition, its predictive effects on soils and management alternatives for re-use for landscape irrigation in and around Riyadh city. The wastewater channel is composed of agricultural drainage water, sewage water, seepage losses from irrigated fields, leakage from water supply systems, runoff from over irrigation and waste effluent from Wastewater Treatment Plant Riyadh. Water samples from 31 locations along Wadi Hanifah stream were collected for quality evaluation for its reuse in landscape irrigation. The SAR and adj.R $R_{N a}$ of wastewater ranged from 4.06-7.66 and 4.7510.75 , respectively. The $B$ concentration was above the permissible limit of $1.0 \mathrm{mg} \mathrm{L}^{-1}$ for crop irrigation. The predicted soil salinity values from hypothetical leaching fractions showed that the soil salinity falls in the category of moderate to highly saline soils where cultivation of moderate Department of Agricultural Engineering, College of food and Agricultural Sciences, King Saud University, P.O. box 2460 Riyadh 11451, Saudi Arabia. E-mail: othmana@ksu.edu.sa 
to high salt tolerant crops is possible provided 15-20\% excess water above crop water requirements is applied as leaching requirement to maintain soil salinity within acceptable limits. Careful analysis, improved irrigation systems and irrigation management practices are key factors for reusing drainage water.

Keywords: Drainage water, irrigation water quality, total water salinity, boron, leaching requirement, predicted soil salinity.

\section{INTRODUCTION}

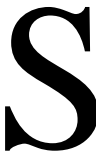

audi Arabia has experienced tremendous urban, rural, agricultural and industrial development over the last two decades which increased manifold the demand of water. The total cropped area in the Kingdom increased from 1.25 million hectares in 1988 to 1.59 million hectares by 1994 (MAW, 1994). Currently, more than $80 \%$ of water demand in agriculture sector is met from non-renewable groundwater sources (MAW, 1994). To meet the growing demand of water for domestic, industrial and agriculture sectors, alternative source of water especially for landscape development and agricultural expansion, has to be explored.

Information is limited on the re-use of waste water in Saudi Arabia. Previous research (Al-Rajhi et al. 1991; Al-Jaloud, 1994; Al-Jaloud et al. 1993, 1995 and Al-A'ama and Nakhla, 1995) addressed some of the issues on the re-use potential of treated sewage for irrigation purposes and its effects on soil and plants.

Irrigation water quality is determined by its physical, chemical and biological parameters as well as the conditions of use. Currently, there is a lot of awareness regarding the water pollution and environmental health hazards resulting from the use of wastewaters. Still, there is a great concern regarding the recycling and reuse of drainage water for irrigation. Besides total water salinity, the presence of certain toxic elements such as $\mathrm{Pb}, \mathrm{Ni}$, $\mathrm{Cd}, \mathrm{Co}, \mathrm{Cu}, \mathrm{Mo}, \mathrm{Hg}$ etc in the drainage waters is likely to create some environmental problems and needs evaluation prior to its re-use for purposes other than agriculture.

Population of Riyadh city has increased manifold over the last 25 years. One of the implications of population increase is the substantial increase in water requirements for different purposes consequently increasing the production of wastewater. As a direct result of massive expansion in size 
and population of Riyadh city, Wadi Hanifah channel has become a significant drainage water disposal outlet. The main objective of this study was to determine wastewater quality and its reuse potential in agriculture with minimum environmental hazards.

\section{Drainage Water Availability}

The wastewater running through Wadi Hanifah channel include agricultural drainage water, run-off losses from irrigation systems and fields, sewage water from cities and villages, leakage from water supply systems, high percolation losses from the irrigated fields, waste effluent from sewage water treatment plant (SWTP) Riyadh and the drainage effluent from aquaculture facilities. Drainage water also contains appreciable amount of plant nutrients such as $\mathrm{N}, \mathrm{P}$ and others (Fe, $\mathrm{Cu}$ etc) and can prove a good source of plant nutrition especially for landscape establishment. Since, the use of reclaimed or treated wastewater for various purposes is in early development stages in Saudi Arabia but offers a good opportunity for considerable expansion in the future with simultaneous increase in population. It was reported in 1985 that wastewater treatment provided only $1 \%$ of the total supply which reached to $23 \%$ in 1998 with $336,000 \mathrm{~m}^{3}$ of treated sewage water being used in agriculture sector (Ministry of Municipal and Rural Affairs, 1999). Figure 1 shows the quantity of wastewater available in some major cities in Saudi Arabia (Hussain and Al-Saati, 1999). Figure 2 shows mean weighted flow in Wadi Hanifah at some sites according to Al-Fayzi and Al-Fateh, 1996. 


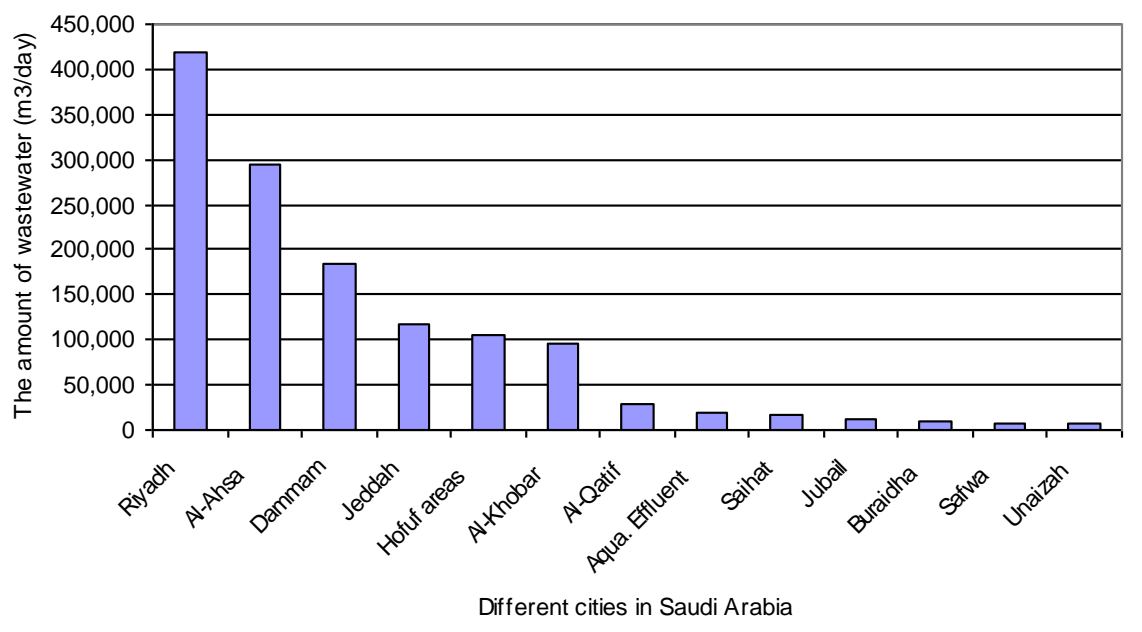

Fig.1. The quantity of wastewater available in some urban centres in Saudi Arabia (Hussain and Al-Saati, 1999).

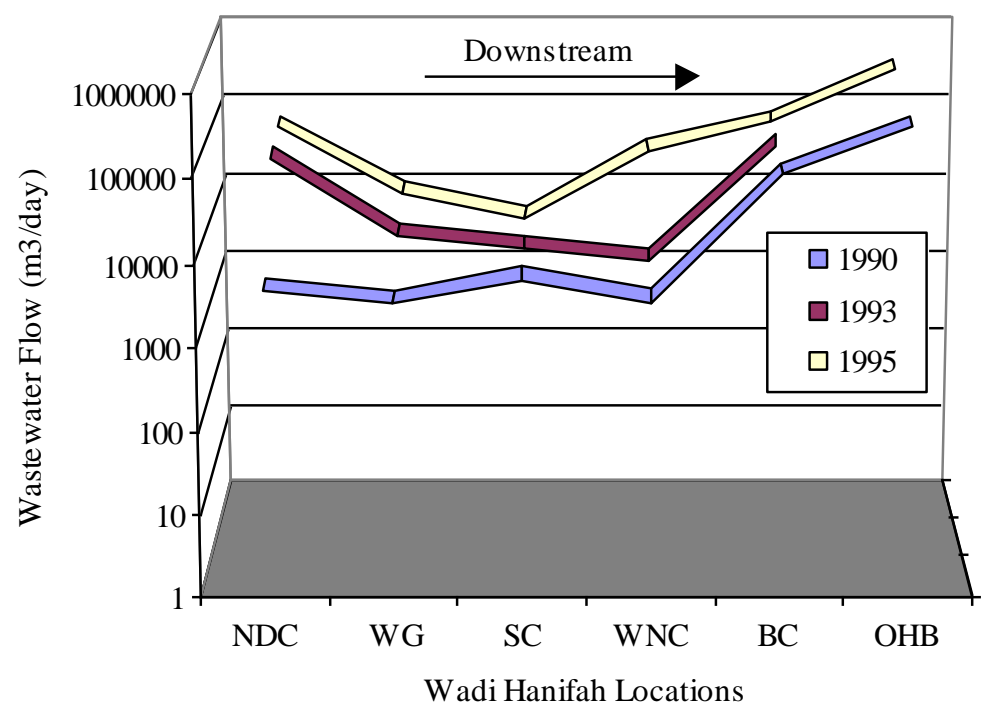

Figure 2: Weighted mean flow at various sites of Wadi Hanifah stream (measured by Al-Fayzi and Al-Fateh, 1996). 


\section{MATERIALS AND METHODS}

A detailed survey was carried out in and around Riyadh city during 20042005 to determine the main drainage network for the disposal of wastewater into the main drainage stream passing through the main city of Riyadh.

A total of 31 drainage water samples were collected from the main drain and the sub-drains along the entire course of Wadi Hanifah channel (Figure 3). The drainage water samples were collected in three different types of bottles (after Shelton, 1994). For chemical analysis, water samples were collected in triplicate in sterilised, acid washed, plastic bottles (capacity one-litre). The bottle was kept airtight to avoid any contamination and stored in an icebox at $4{ }^{\circ} \mathrm{C}$ until analyzed. The analytical procedures used for these determinations were those described in USDA, 1954.

\section{Water Quality Indicators for Landscape Irrigation}

The criteria used to evaluate quality of drainage/wastewater for use in agriculture are 1) Salinity of irrigation water for salt build up in soils and its adverse effects on plant growth, 2) Sodium Adsorption Ratio (SAR) for its deleterious effect on soil physical properties, 3) Residual Sodium Carbonate (RSC) for its effects on final soil water SAR value with the loss or gain in $\mathrm{Ca}$ and $\mathrm{Mg}$ concentration due to the precipitation or dissolution of alkaline earth carbonates, and the Toxic effects of Specific Ions in irrigation water such as $\mathrm{Na}, \mathrm{Cl}, \mathrm{SO}_{4}$ and $\mathrm{B}$ on plant growth and yield (FAO, 1985).

Besides the above indicators, some mathematical equations and models were applied to evaluate the water quality for its reuse as irrigation in the main Metropolitan City Riyadh for the development of community recreational sites. Soil salinity development (SSD), adjusted sodium adsorption ratio (adj. $\mathrm{R}_{\mathrm{Na}}$ ), and exchangeable sodium percentage (ESP) were calculated from the analytical data. 


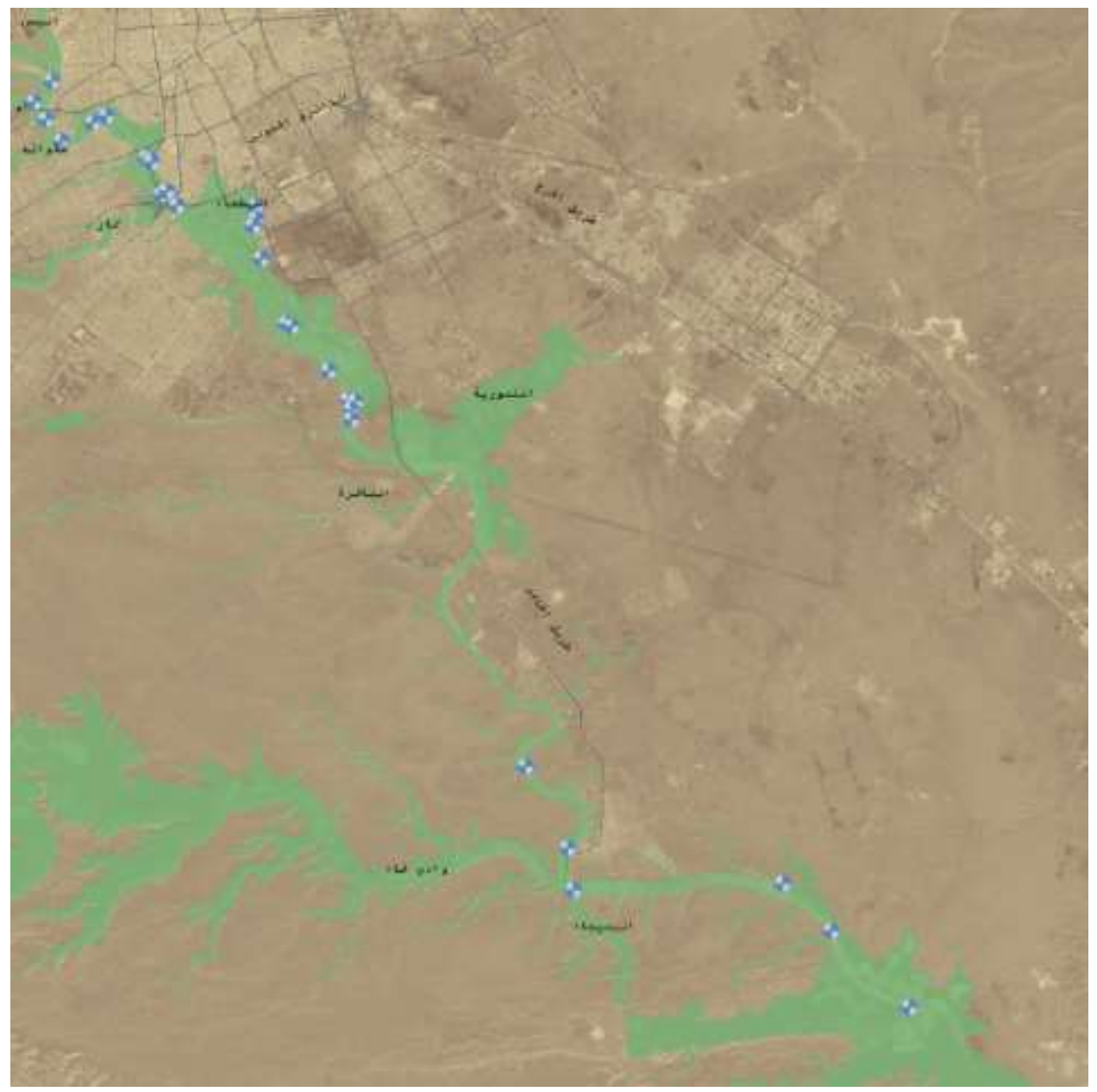

Fig. 3. Location map of different sampling stations in main Wadi Hanifah water stream.

(a) The SSD was calculated by the following equation according to Ayers and Westcot, 1985. $\quad \mathrm{SSD}=\mathrm{EC}_{\mathrm{dw}}=\mathrm{EC}_{\mathrm{iw}} / \mathrm{LF}$

Where: $\mathrm{EC}_{\mathrm{dw}}$ Salinity of the drainage water percolating below the root zone.

$\mathrm{EC}_{\mathrm{iw}}$ Salinity of the drainage water to be used for irrigation.

LF Leaching fraction is the amount of irrigation water that leaves the root zone as drainage water.

(a). The sodium adsorption ratio (SAR) was calculated as below (USDA, 1954): 


$$
\mathrm{SAR}=\mathrm{Na} /[(\mathrm{Ca}+\mathrm{Mg}) / 2]^{1 / 2}
$$

(b) The adj. $\mathrm{R}_{\mathrm{Na}}$ was determined according to Suarez (1981) using the following equation:

$$
\operatorname{adj} . \mathrm{R}_{\mathrm{Na}}=\mathrm{Na} /\left[\left(\mathrm{Ca}_{\mathrm{x}}+\mathrm{Mg}\right) / 2\right]^{0.5}
$$

where all concentrations in meq $\mathrm{L}^{-1}, \mathrm{Ca}_{\mathrm{x}}$ represents concentration after counting for $\mathrm{HCO}_{3}$ of wastewaters.

(C) The ESP was predicted as:

$$
\mathrm{ESP}=\frac{100(-0.0126+0.01475 \times \mathrm{SAR})}{-}
$$

where SAR is the SAR of the soil solution resulting from irrigation with drainage waters.

The salinity and sodicity hazards of the drainage waters were determined according to the classification given by USDA Handbook No. 60, 1954.

The drainage waters were also categorized for landscape irrigation and crop production according to the standards of Ayers and Westcot (1985).

The chemistry data were evaluated by applying various statistical techniques according to Snedecor and Cochran, 1973.

\section{RESULTS AND DISCUSSION}

\section{Chemistry of Drainage Water}

The ranges of different water quality parameters were $1.76-5.37 \mathrm{dS} \mathrm{m}^{-1}$ (EC), (all other cations and anions expressed as mg L-1) 1252-4263 (TDS), 168-571 (Ca),47-161 (Mg), 231-764 (Na), 15-30 (K), 163-274 $\left(\mathrm{HCO}_{3}\right), 279-826(\mathrm{Cl}), 414-1497\left(\mathrm{SO}_{4}\right), 22-136\left(\mathrm{NO}_{3}\right), 4.06-7.66$ (SAR) and 4.1-10.75 (adj. $\left.\mathrm{R}_{\mathrm{Na}}\right)$ in the drainage water of Riyadh city at different locations (Table 2). The order of abundance for cations was $\mathrm{Na}>\mathrm{Ca}>$ $\mathrm{Mg}$, while that of anions was $\mathrm{SO}_{4}>\mathrm{Cl}>\mathrm{HCO}_{3}$. A significant correlation was found between $\mathrm{Na}$ and $\mathrm{Cl}$ ions $\left(\mathrm{R}^{2}=0.927\right), \mathrm{Ca}$ and $\mathrm{Cl}$ ions $\left(\mathrm{R}^{2}=0.795\right)$ and $\mathrm{Mg}$ and $\mathrm{Cl}\left(\mathrm{R}^{2}=0.842\right)$ in the drainage water of Riyadh city. This indicated that that the drainage water of Riyadh city is mainly $\mathrm{Na}, \mathrm{Ca}$ and $\mathrm{SO}_{4}$ water. Thermodynamic calculations revealed that a significant fraction of $\mathrm{Ca}$ and $\mathrm{Mg}$ in the groundwater was associated with $\mathrm{SO}_{4}$ and $\mathrm{HCO}_{3}$. The regression analysis showed (Fig. 4) a strong 
relationship between EC and SAR as well as between EC and adj. $\mathrm{R}_{\mathrm{Na}}$ of drainage water $\left(R^{2}=0.677\right.$ and 0.792 for $S A R$ and adj. $R_{N a}$, respectively). The results agree with those of Hussain and Sadiq (1991) who reported drainage water salinity between 1000 and $7273 \mathrm{mg} \mathrm{L}^{-1}$ in Al-Ahsa drainage water. They also observed that the drainage water salinity depends on the type and nature of drainage water.

The drainage waters were classified as C3S1 to C4S3 i.e. that is high to very high salinity and slight to very high sodicity problems (USDA, 1954). The drainage water could be used for irrigation provided certain management practices such as application of leaching requirement, selection of medium to high salt tolerant crops and improved irrigation system (drip or subsurface) are adopted in order to keep the soil salinity within acceptable limits for crop production and landscape development.

\section{Ion Inter-Relationships}

The regression analysis showed strong relationship between $\mathrm{Na}$ vs $\mathrm{Cl}$ ions $\left(\mathrm{R}^{2}=0.928\right)$, between $\mathrm{Ca}$ vs $\mathrm{Cl}\left(\mathrm{R}^{2}=0.795\right)$ and, between $\mathrm{Mg}$ vs $\mathrm{Cl}$ $\left(\mathrm{R}^{2}=0.842\right.$; Fig. 5) as well as between $\mathrm{Ca}$ and $\mathrm{SO}_{4}\left(\mathrm{R}^{2}=0.912\right)$ and between $\mathrm{Mg}$ vs $\mathrm{SO}_{4}$ ions $\left(\mathrm{R}^{2}=0.850\right)$ in the drainage water of Riyadh City (Fig. 6). With increased $\mathrm{SO} 4$, the $\mathrm{Ca}$ and $\mathrm{Mg}$ values tend to increase indicating an interaction between the aqueous and the solid phases. However, there is no evidence of any other relationship among various cations in the drainage water.

\section{Cations and Anions Ratios}

The Ca concentration is 1.39 -2.71 times higher than $\mathrm{Mg}$ in the drainage water of Riyadh (Fig. 4). This revealed that $\mathrm{Ca}$ dominant soils will develop and improve the soil structure with drainage water irrigation. The drainage water is a $\mathrm{Na}-\mathrm{Ca}$ and $\mathrm{Mg}$ type water.

The $\mathrm{SO}_{4}$ ion was the dominant anion than the $\mathrm{Cl}$ ion in the drainage water and the ratio ranged between 0.925 and 1.95 (Fig.7). The high sulphate $\left(\mathrm{SO}_{4}\right)$ concentration than chloride $(\mathrm{Cl})$ might be due to the land disposal of industrial waste effluents rich in sulphur compounds.

\section{Effect of Drainage Water Quality on Soil Properties}

Besides fresh irrigation supplies, the available drainage water is an alternative source of irrigation for sustainable landscape development and crop production in the suburbs of Capital City Riyadh. Therefore, the 
effect of the prolonged use of drainage water for irrigation was predicted on soil salinity and the sodium hazards. The SAR of drainage water was calculated. This information was used to calculate adj. $\mathrm{R}_{\mathrm{Na}}$ which accounts for alkalinity hazards and the exchangeable-sodium-percentage (ESP) of soil. The SAR of drainage water ranged from 4.06-7.66 with the corresponding adj. $\mathrm{R}_{\mathrm{Na}}$ value of 4.75-10.75 (Table $2 \&$ Fig. 8). The predicted exchangeable-sodium-percentage (ESP) using drainage water for irrigation is presented in Fig. 8. The ESP values predicted from adj. $\mathrm{R}_{\mathrm{Na}}$ are much higher than those predicted from the normal SAR of drainage water. But the predicted ESP of soil from both the SAR and adj. $\mathrm{R}_{\mathrm{Na}}$ does not show any sodicity hazards upon irrigation with drainage water. Because, the upper safe limit of ESP value for soil is 15 according to USDA, 1954, hence there is no immediate concern of soil sodicity problem from drainage water irrigation. In the case of long term irrigation practice, there might be some soil sodicity problems which could be managed if management practice such as leaching requirement (application of 15-20\% excess water above crop ET requirements) is followed to keep soil salinity and sodicity within safe limits.

Development of soil salinity from drainage water irrigation was predicted using five hypothetical leaching fractions ranging from 0.15-0.40\% (Fig.9). It was noticed that those locations, where drainage water EC is less than $2.5 \mathrm{dS} \mathrm{m}^{-1}$, might develop soil salinity more than $10 \mathrm{dS} \mathrm{m}^{-1}$. This indicated that cultivation of moderate to high salt tolerant crops is possible provided $15-20 \%$ excess water above crop water requirements (ET) is applied as leaching requirement to maintain soil salinity within acceptable limits.

\section{Nitrate ( $\left.\mathrm{NO}_{3}\right)$ Concentration}

Most of the nitrogen in the drainage water is probably derived from the biosphere and land disposal of sewage effluent. Mean nitrate concentration $\left(\mathrm{mg} \mathrm{L}^{-1}\right)$ in drainage water of Riyadh city ranged from 17.5-135.6 (Table 2). The ammonium compounds in the drainage water are oxidized and converted to more stable nitrogen compounds such as nitrate form of nitrogen (Al-Jaloud et al., 1993). The maximum permissible limit of nitrate concentration in water for irrigation purpose 
is $45 \mathrm{mg} \mathrm{L}^{-1}$ according to WHO (1984). Data revealed that about $18 \%$ of the total drainage water samples contained high nitrate concentration which is above the permissible limits for agriculture use and needs pretreatment before its intended use.

\section{Phosphate ( $\left.\mathrm{PO}_{4}\right)$ Concentration}

The $\mathrm{PO}_{4}$ contents ranged between 0.162 and $21.910 \mathrm{mg} \mathrm{L}^{-1}$ in the drainage water of Riyadh City (Table 2). Ion inter-relationship analysis showed good relation between $\mathrm{Ca}$ and $\mathrm{PO}_{4}$ ion $\left(\mathrm{R}^{2}=0.654\right)$ and between $\mathrm{Mg}$ and $\mathrm{PO}_{4}\left(\mathrm{R}^{2}=0.629\right)$ whereas a poor relation was observed between $\mathrm{Na}$ and $\mathrm{PO}_{4}$ ions $\left(\mathrm{R}^{2}=0.429\right)$. This suggested that most of the $\mathrm{PO}_{4}$ ion is associated with $\mathrm{Ca}$ and $\mathrm{Mg}$ ions. Data also revealed that about $55 \%$ of drainage water samples from different locations of Riyadh District contain $\mathrm{PO}_{4}$ higher than the established standards $\left(3 \mathrm{mg} \mathrm{L}^{-1}\right)$ of MEPA, Saudi Arabia (MEPA, 1988) and requires consideration.

\section{Boron (B) Concentration}

Mean B contents ranged between 0.74 and $1.51 \mathrm{mg} \mathrm{L}^{-1}$ (Table 2). The safe limit of B content in irrigation water is less than $0.7 \mathrm{mg} \mathrm{L}^{-1}$ for crop irrigation (Mass, 1984 and Ayers and Westcot, 1985). The B concentration above this level can create toxicity in plants, create health hazards and could be a potential source of environmental pollution when used for crop irrigation (Lucho-Constantino et al., 2005). The permissible limits of boron contents in irrigation water are given in Table 3. The results revealed that most of the drainage water samples contains high level of B. The high B contents might be due to increased use of borax powder for the preparation of different types of detergents and later on the waste effluent from these small industries is released to the main Wadi Hanifah stream. The maximum permissible levels of different metal concentration in irrigation water according to Ministry of Agriculture and Water, Riyadh, Saudi Arabia is presented in Table 4.

\section{CONCLUSION}

The salinity and sodicity hazards of drainage water of Riyadh were classified as $\mathrm{C} 3 \mathrm{~S} 1$ to $\mathrm{C} 4 \mathrm{~S} 3$ i.e. that is high to very high salinity and slight to very high sodicity problems. A strong relationship existed between $\mathrm{Na}$ and $\mathrm{Cl}$ ions $\left(\mathrm{R}^{2}=0.9276\right)$, between $\mathrm{Ca}$ and $\mathrm{Cl}\left(\mathrm{R}^{2}=0.795\right)$ and, between $\mathrm{Mg}$ and $\mathrm{Cl}\left(\mathrm{R}^{2}=0.842\right.$; Fig. 5). Also, a strong relationship was found 
between $\mathrm{Ca}$ and $\mathrm{SO}_{4}\left(\mathrm{R}^{2}=0.912\right)$ and between $\mathrm{Mg}$ and $\mathrm{SO}_{4}$ ions $\left(\mathrm{R}^{2}=0.850\right)$ in the drainage water of Riyadh City. The Ca concentration is $1.39-2.71$ times higher than $\mathrm{Mg}$. The $\mathrm{SO}_{4}$ is the dominant anion rather than $\mathrm{Cl}$ ion in the drainage water and the ratio ranged from 0.925 to 1.95 . The SAR ranged from 4.06-7.66 with the corresponding adj. $\mathrm{R}_{\mathrm{Na}}$ value of 4.75-10.75. The predicted ESP values from the adj. $R_{N a}$ are much higher than those predicted from the normal SAR of drainage water and does not show any sodicity hazards upon irrigation with drainage water. Mean nitrate concentration ( $\mathrm{mg} \mathrm{L}^{-1}$ ) varies from 17.5 and 135.6 and around 18 $\%$ water samples are above the maximum permissible limit of $40 \mathrm{mg} \mathrm{L}^{-1}$. The $\mathrm{PO}_{4}$ contents ranged between 0.162 and $21.910 \mathrm{mg} \mathrm{L}^{-1}$ in the drainage water of Riyadh City. Ion inter-relationship showed good relation between $\mathrm{Ca}$ and $\mathrm{PO}_{4}$ ion $\left(\mathrm{R}^{2}=0.0654\right)$ and between $\mathrm{Mg}$ and $\mathrm{PO}_{4}$ $\left(\mathrm{R}^{2}=0.629\right)$ whereas a poor relation was observed between $\mathrm{Na}$ and $\mathrm{PO}_{4}$ ions $\left(\mathrm{R}^{2}=0.429\right)$. Mean $B$ contents ranged between 0.74 and $1.51 \mathrm{mg} \mathrm{L}^{-1}$. The predicted soil salinity falls in the category of moderate to highly saline soil. Application of $15-20 \%$ excess water as leaching should be considered to maintain soil salinity within acceptable limits.

\section{Recommendations}

Presently, the drainage water is moderate to high salinity water, contains high level of nitrates and phosphate ions, and the $\mathrm{B}$ concentration is also above the permissible limits. Therefore, Its reuse in agriculture is recommended only under special conditions fulfilling the recommendations made elsewhere. Further studies are required for its micro-biological evaluation for its safe use as a supplementary source of irrigation.

\section{Acknowledgment}

The author would like to acknowledge ArRiyadh Devlepombemt Authority for their cooperation regarding the provision of drainage water data of Riyadh City. 
Table 2. Chemical Composition of Drainage Water of Riyadh District.

\begin{tabular}{|c|c|c|c|c|c|c|c|c|c|c|c|c|c|c|c|c|}
\hline Sr.No & Location & $\mathrm{pH}$ & $\mathrm{EC} \mathrm{dS} \mathrm{m}{ }^{-1}$ & $\begin{array}{c}\mathrm{TDS} \\
\mathrm{mg} \mathrm{L}^{-1}\end{array}$ & $\begin{array}{c}\mathrm{Ca} \\
\mathrm{mg} \mathrm{L}^{-1}\end{array}$ & $\begin{array}{c}\mathrm{Mg} \\
\mathrm{mg} \mathrm{L}^{-1}\end{array}$ & $\begin{array}{c}\mathrm{Na} \\
\mathrm{mg} \mathrm{L}^{-1}\end{array}$ & $\begin{array}{c}\mathrm{K} \\
\mathrm{mg} \mathrm{L}^{-1} \\
\end{array}$ & $\begin{array}{l}\mathrm{HCO}_{3} \\
\mathrm{mg} \mathrm{L}^{-1} \\
\end{array}$ & $\begin{array}{c}\mathrm{Cl} \\
\mathrm{mg} \mathrm{L}^{-1}\end{array}$ & $\begin{array}{c}\mathrm{SO}_{4} \\
\mathrm{mg} \mathrm{L}^{-1} \\
\end{array}$ & SAR & $\begin{array}{c}\mathrm{NO}_{3} \\
\mathrm{mg} \mathrm{L}^{-1} \\
\end{array}$ & $\begin{array}{c}\mathrm{PO}_{4} \\
\mathrm{mg} \mathrm{L}^{-1} \\
\end{array}$ & $\begin{array}{c}\text { B mg } \\
\mathrm{L}^{-1}\end{array}$ & Water Class \\
\hline 1 & SW1c & 7.90 & 4.654 & 3712 & 542.87 & 138.8 & 564.75 & 33.05 & 224.4 & 826 & 1466 & 5.58 & 116.1 & 1.226 & 1.45 & C4S2 \\
\hline 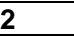 & SW4c & 8.04 & 4.065 & 3130 & 495.5 & 110.7 & 499.20 & 17.30 & 273.6 & 535 & 1411 & 5.26 & 73.1 & 0.548 & 1.48 & C4S2 \\
\hline 3 & SW22 & 7.89 & 4.825 & 3777 & 571.1 & 150.6 & 565.18 & 29.83 & 248.4 & 818 & 1455 & 5.42 & 108.9 & 0.972 & 1.51 & C4S2 \\
\hline & SW5c & 7.94 & 3.648 & 2722 & 436.69 & 96.8 & 414.47 & 18.84 & 252.2 & 470 & 1332 & 4.66 & 67.2 & 0.605 & 1.35 & C4S2 \\
\hline 5 & SW5d & 7.86 & 4.72 & 3690 & 486.21 & 135.0 & 553.01 & 28.17 & 249 & 769 & 1469 & 5.7 & 117.7 & 0.782 & 1.41 & C4S2 \\
\hline 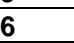 & SW2c & 8.20 & 1.974 & 1429 & 221 & 68.3 & 252.50 & 18.80 & 192.6 & 363 & 454 & 3.79 & 19.0 & 3.512 & 0.74 & C3S1 \\
\hline & SW2b & 7.85 & 4.685 & 3656 & 493.69 & 138.9 & 558.64 & 28.67 & 237.6 & 781 & 1447 & 5.7 & 95.1 & 0.730 & 1.47 & C4S2 \\
\hline 3 & SW3a & 7.93 & 4.769 & 3728 & 560.27 & 149.5 & 597.18 & 29.37 & 259.8 & 798 & 1497 & 5.77 & 99.0 & 0.656 & 1.52 & C4S2 \\
\hline 9 & SW3c & 8.04 & 2.511 & 1845 & 312.79 & 115.4 & 296.79 & 24.55 & 222 & 350 & 817 & 3.63 & 27.9 & 0.334 & 1.07 & C4S1 \\
\hline 10 & SW12a & 7.96 & 4.022 & 3037 & 408.03 & 133.4 & 449.57 & 26.29 & 227.4 & 623 & 1291 & 4.92 & 78.6 & 0.516 & 1.25 & C4S2 \\
\hline 11 & SW6a & 8.05 & 5.367 & 4263 & 483.86 & 161.1 & 763.91 & 15.53 & 223.8 & 967 & 1561 & 7.66 & 135.6 & 0.162 & 1.22 & C4S3 \\
\hline 12 & SW6b & 8.01 & 4.088 & 3146 & 433.98 & 131.7 & 456.42 & 27.05 & 227.4 & 664 & 1337 & 4.91 & 77.9 & 0.676 & 1.28 & C4S2 \\
\hline 13 & SW12c & 7.99 & 3.999 & 3112 & 398.62 & 123.6 & 415.69 & 25.99 & 226.8 & 662 & 1326 & 4.65 & 86.3 & 0.676 & 1.13 & C4S2 \\
\hline 14 & SW8a & 8.21 & 2.262 & 1649 & 305.21 & 72.5 & 245.30 & 21.74 & 187.8 & 295 & 685 & 3.27 & 28.7 & 1.183 & 0.85 & C4S1 \\
\hline 15 & SW8b & 7.53 & 1.944 & 1398 & 218.4 & 53.5 & 262.21 & 23.91 & 169.8 & 309 & 504 & 4.11 & 18.4 & 13.824 & 0.94 & C3S1 \\
\hline 16 & $\begin{array}{l}\text { SOUTH } \\
\text { STP }\end{array}$ & 7.50 & 1.757 & 1252 & 168.32 & 46.5 & 231.47 & 21.97 & 187.2 & 279 & 414 & 4.06 & 21.9 & 21.910 & 0.79 & C3S1 \\
\hline 17 & SW8c & 7.60 & 1.947 & 1396 & 203.35 & 50.8 & 271.40 & 22.59 & 162.6 & 317 & 477 & 4.4 & 17.5 & 15.686 & 0.93 & C3S1 \\
\hline 18 & SW14 & 7.93 & 4.048 & 3108 & 472.9 & 133.5 & 468.02 & 23.61 & 212.4 & 640 & 1345 & 4.88 & 83.8 & 0.534 & 1.22 & C4S2 \\
\hline 19 & SW20 & 7.94 & 3.107 & 2333 & 407.3 & 106.4 & 404.04 & 23.05 & 195.6 & 508 & 870 & 4.59 & 50.7 & 9.190 & 0.95 & C4S2 \\
\hline 20 & SW21 & 7.97 & 2.911 & 2172 & 337.65 & 88.9 & 361.28 & 22.90 & 185.4 & 470 & 829 & 4.51 & 50.4 & 9.022 & 0.88 & C4S2 \\
\hline 21 & SW8d & 8.01 & 2.903 & 2164 & 311.63 & 90.2 & 360.33 & 22.37 & 185.4 & 476 & 838 & 4.61 & 48.7 & 9.232 & 0.86 & C4S2 \\
\hline 22 & SW8f & 7.83 & 3.995 & 3095 & 372 & 160.9 & 514.85 & 26.00 & 245.4 & 640 & 1265 & 5.6 & 37.3 & 4.396 & 1.21 & C4S2 \\
\hline 23 & SW8e & 7.98 & 2.626 & 1939 & 301.91 & 84.4 & 332.50 & 22.04 & 172.8 & 423 & 752 & 4.35 & 38.4 & 11.669 & 0.82 & C4S2 \\
\hline 24 & SW8g & 7.96 & 2.652 & 1957 & 251.54 & 78.1 & 323.95 & 21.70 & 183 & 435 & 739 & 4.56 & 41.1 & 11.663 & 0.81 & C4S2 \\
\hline 25 & SW9b & 7.96 & 2.461 & 1807 & 271.25 & 78.7 & 339.34 & 21.04 & 163.2 & 382 & 634 & 4.65 & & 12.395 & 1.42 & C4S2 \\
\hline 26 & SW9a & 7.87 & 2.473 & 1814 & 258.9 & 78.2 & 323.51 & 20.75 & 174 & 372 & 640 & 4.51 & & 11.898 & 1.38 & C4S2 \\
\hline 27 & SW15 & 7.79 & 2.513 & 1853 & 246.9 & 80.4 & 336.38 & 20.50 & 184.8 & 390 & 660 & 4.74 & & 10.842 & 1.34 & C4S2 \\
\hline 28 & SW10b & 7.60 & 2.563 & 1890 & 259.3 & 79.4 & 334.32 & 20.50 & 175.8 & 392 & 682 & 4.65 & & 12.315 & 1.21 & C4S2 \\
\hline 29 & SW11a & 7.85 & 3.131 & 2364 & 297.77 & 103.4 & 426.05 & 19.63 & 258.6 & 496 & 864 & 5.4 & & 8.419 & 1.17 & C4S2 \\
\hline 30 & SW11b & 7.72 & 2.453 & 1800 & 252.34 & 78.2 & 333.90 & 19.64 & 175.8 & 385 & 652 & 4.69 & & 12.217 & 0.99 & C4S2 \\
\hline 31 & SW16 & 7.81 & 2.515 & 1826 & 263.7 & 81.7 & 332.10 & 19.94 & 179.4 & 389 & 672 & 4.57 & & 11.055 & 0.90 & C4S2 \\
\hline
\end{tabular}

Misr J. Ag. Eng., October 2008 
Table 3. Permissible Limits of Boron $\left(\mathrm{mg} \mathrm{L}^{-1}\right)$ in Irrigation Water**

\begin{tabular}{|l|l|l|l|}
\hline Class of Water & Sensitive Crops & Semi-Tolerant Crops & Tolerant Crops \\
\hline Excellent & $<0.33$ & $<0.67$ & $<1.00$ \\
\hline Good & $0.33-0.67$ & $0.67-1.33$ & $1.00-2.00$ \\
\hline Permissible & $0.67-1.00$ & $1.33-2.00$ & $2.00-3.00$ \\
\hline Doubtful & $1.00-1.25$ & $2.00-2.50$ & $3.00-3.75$ \\
\hline Unsuitable & $>1.25$ & $>2.50$ & $>3.75$ \\
\hline
\end{tabular}

** Source (FAO, 1985)

Table 4. Maximum Contamination Levels in Restricted and Unrestricted Irrigation Waters (Draft Standards by Ministry of Agriculture and Water).

\begin{tabular}{|c|c|c|}
\hline Parameters & $\begin{array}{l}\text { Unrestricted } \\
\text { Irrigation }\end{array}$ & $\begin{array}{l}\text { Restricted } \\
\text { Irrigation }\end{array}$ \\
\hline Biochemical Oxygen Demand & $10-15$ & $20-30$ \\
\hline Total Suspended Solids (TSS) & 10 & 20 \\
\hline Aluminum $(\mathrm{Al})$ & 5 & 5 \\
\hline Arsenic (As) & 0.1 & 0.1 \\
\hline Beryllium $(\mathrm{Be})$ & 0.1 & 0.1 \\
\hline Boron $(\mathrm{B})$ & 0.5 & 0.5 \\
\hline Cadmium $(\mathrm{Cd})$ & 0.01 & 0.01 \\
\hline Chromium $(\mathrm{Cr})$ & 0.01 & 0.01 \\
\hline Cobalt $(\mathrm{Co})$ & 0.05 & 0.05 \\
\hline Copper $(\mathrm{Cu})$ & 0.4 & 0.4 \\
\hline Cyanide & 0.05 & 0.05 \\
\hline Fluoride $(\mathrm{F})$ & 2 & 2 \\
\hline Iron $(\mathrm{Fe})$ & 5 & 5 \\
\hline Lead $(\mathrm{Pb})$ & 0.1 & 0.1 \\
\hline Lithium (Li) & 2.5 & 2.5 \\
\hline Manganese (Mn) & 0.2 & 0.2 \\
\hline Mercury $(\mathrm{Hg})$ & 0.001 & 0.001 \\
\hline Molybdenum (Mo) & 0.01 & 0.01 \\
\hline Nitrate as $\mathrm{N}$ & 10 & 10 \\
\hline Selenium $(\mathrm{Se})$ & 0.02 & 0.02 \\
\hline Vanadium $(\mathrm{V})$ & 0.01 & 0.01 \\
\hline Zinc $(\mathrm{Zn})$ & 4 & 4 \\
\hline $\mathrm{pH}$ & 6.0 & 8.0 \\
\hline Fecal Coliform (MPN)/100 ml & $5-100$ & $20-200$ \\
\hline Turbidity, NTU & 1 & 1 \\
\hline
\end{tabular}




\section{REFERENCES}

Al-A'ama, M. S., and Nakhla, G. F. 1995. Wastewater reuse in Jubail, Saudi Arabia. Water Research. 29 (6), 1579-1584.

Al-Degaither, M. 1992. Preserving the Kingdom's limited natural resources, Riyadh Daily,

March 3.

Al-Fayzi, S. A. and Al-Fateh, M. 1996. Program for Control High Groundwater Level in Riyadh. Proceedings of symposium on Wastewater Treatment Technology and Reuse, Riyadh, Saudi Arabia 18-20 November 1996, pp 185-204. College of Engineering-King Saud University and Riyadh Region Water and Sewerage Authority, Riyadh, Saudi Arabia.

Al-Jaloud, A. (1994). Effect of Irrigation with Treated Municipal wastewater on Soil and Crops. Met. , Environment Arid Land Agricultural Science, 5, 77-88.

Al-Jaloud, A., Hussain, G., Al-Saati, A., and Karimullah, S. (1993) Effects of Wastewater on Plant Growth and Soil Properties. Arid Soil Research and Rehabilitation, 7, 173-179.

Al-Jaloud, A., Hussain, G., Al-Saati, A., and Karimullah, S. (1995) Effect of Wastewater Irrigation on Mineral Composition of Corn and Sorghum Plants in a Pot Experiment. Journal of Plant Nutrition, 18(8), 1677-1692.

Al-Rajhi, D., A. Al-Jaloud, and A. Shams. 1991. The possible reuse of treated municipal wastewater in agricultural irrigation and associated adverse effects on plants, animals and humans. Final Report, Project No. AR-9-36. King Abdulaziz City for Science and Technology, Riyadh, Saudi Arabia.

Arriyadh Development Authority (ADA) 1990. The Rising Groundwater Management Program. Volume 1. High Commission for Development of Arriyadh. Riyadh. Saudi Arabia.

Ayers, R. S. and D. W. Westcot 1985. Water Quality for Agriculture. Irrigation and Drainage Paper 29 Rev. 1. FAO, Rome. 174 p.

HIDA. Water Research Department, Annual Report. 1984. Hassa Irrigation and Drainage Authority, Hofuf, Saudi Arabia. 
Hussain G. and Al-Saati, A. J. 1999. Wastewater quality and its reuse in agriculture in Saudi Arabia. Desalination. 123, 241-251.

Hussain, G. and M. Sadiq. 1991. Metal chemistry of irrigation anD drainage waters of Al-Ahsa Oasis of Saudi Arabia

and its effects on soil properties. Water, Air and Soil Pollution 5758:773-783.

Ishaq, A. M. 1992. Surface and subsurface drainage of metropolitan city in arid zone. Journal of Irrigation and Drainage Engineering. ASCE. 118(1), . 19-35

Lucho-Constantino, C.A., Prieto-Garcia, F., Del Razo, L.M., RodriguezVazquez,R., and Poggi-Varaldo, H.M. 2005. Chemical fractionation of boron and heavy metals in soils irrigated wastewater in central Mexico. Agriculture Ecosyastems and Environment. 108, 57-71.

Mass, E. V. 1984. Salt tolerance of plants. In: The Handbook of Plant Science in Agriculture, B. R. Christie (ed). CRC Press, BocaRaton, Florida, USA.

Meteorology and Environmental Protection Administration (MEPA).1988. Environmental Protection Standards (General Standards), Document No. 1409-1, Kingdom of Saudi Arabia.

Ministry of Agriculture and Water. 1994. Agriculture Statistical Year Book. Vol.9. Department of Economic Studies and Statistics. Ministry of Agriculture and Water, Riyadh, Saudi Arabia.

Ministry of Municipal and Rural Affairs. Annual Report, 1999.

Rushton, K. R. and Al-Othman, A. A. R. 1994. Control of rising groundwater levels in Riyadh, Saudi Arabia. In Wilkinson, W. B. (ed) Groundwater problems in urban areas; proceedings of the international conference, pp. 299-309. Thomas Telford, London, United Kingdom.

Shelton, L.R., and Capel, P.D. 1994. Guidelines for collecting and processing samples of stream bed sediment for analysis of trace elements and organic contaminants for the National Water-Quality Assessment Program: U.S. Geological Survey Open-File Report 94458.

Snedecor, G. W. and W. G. Cochran. 1973. Statistical Methods, $6^{\text {th }}$ ed. Iowa University Press, Ames. 
Suarez, D. L. 1981. Relation between $\mathrm{pHc}$ and sodium adsorption ratio (SAR) and an alternate method of estimating

SAR of soil or drainage water. Soil Sci. Soc. Amer. J. 45:469-475.

United Nations. 1977. Desertification: Its causes and consequences, New york; Pergamon

Press.United States Department of Agriculture. 1954. Diagnosis and Improvement of Saline and Alkali Soils, USDA Handbook No. 60. U.S. Government Printing Office, Washington, DC.

WHO. 1984. Guidelines for Drinking Water Quality. Vol. 2. Health Criteria and Other Supporting Information.

Geneva: World Health Organization.

WHO. 1989. Health guidelines for the use of wastewater in agriculture and aquaculture. Technical Report No.

778. WHO, Geneva 74 p.

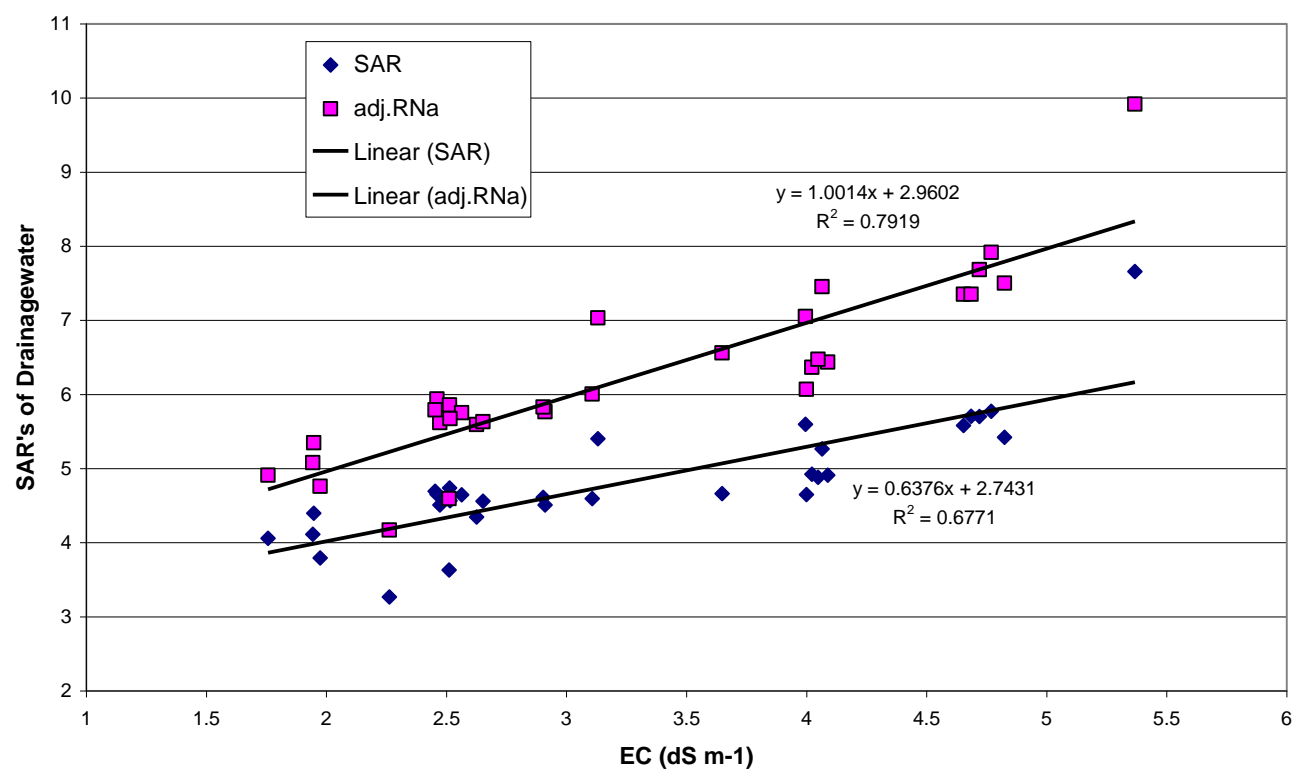

Fig.4. Relationship between EC and SAR's of Drainagewater of Riyadh 


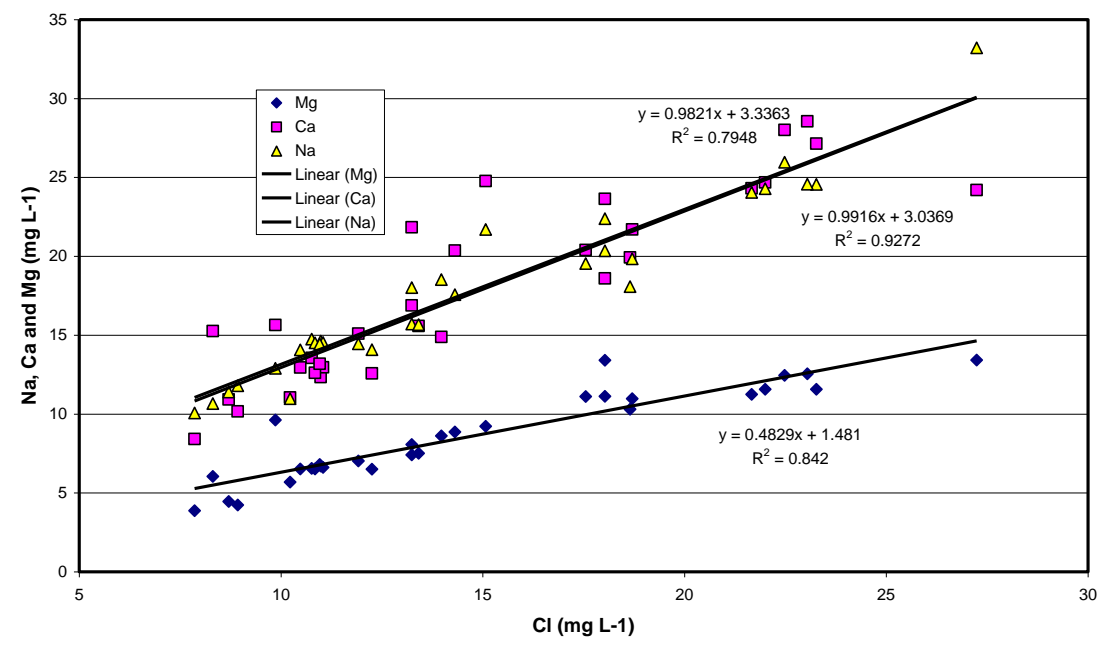

Fig.5. Ion Inter-Relationships in Drainagewater of Riyadh

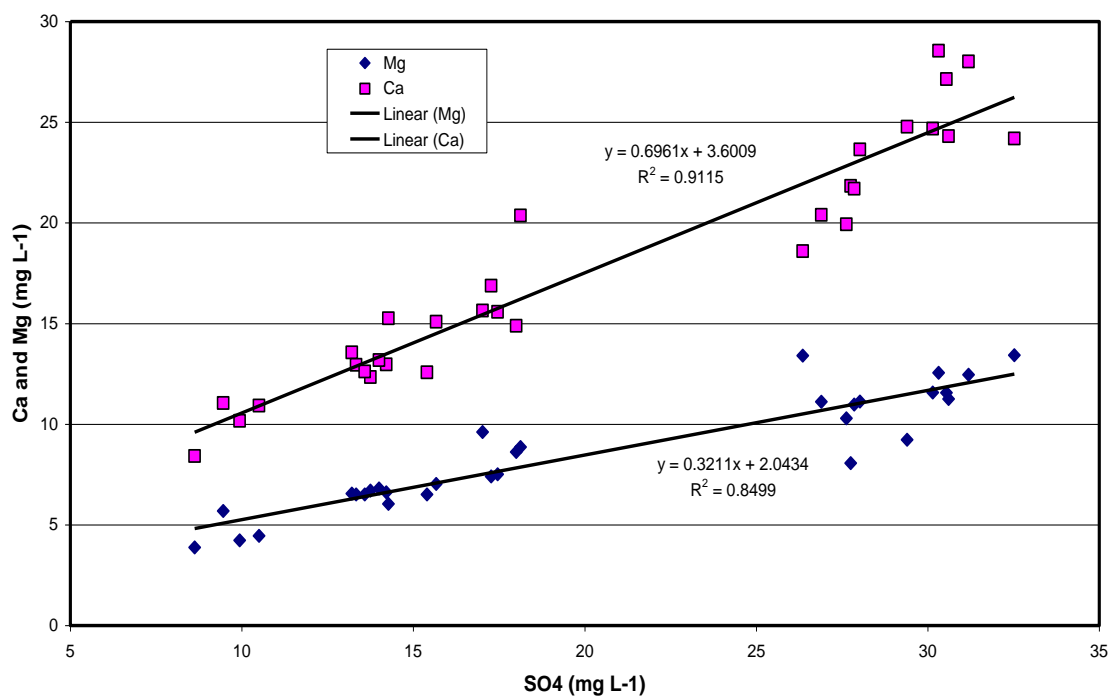

Fig.6. Ion Relationships in Drainagewater of Riyadh 


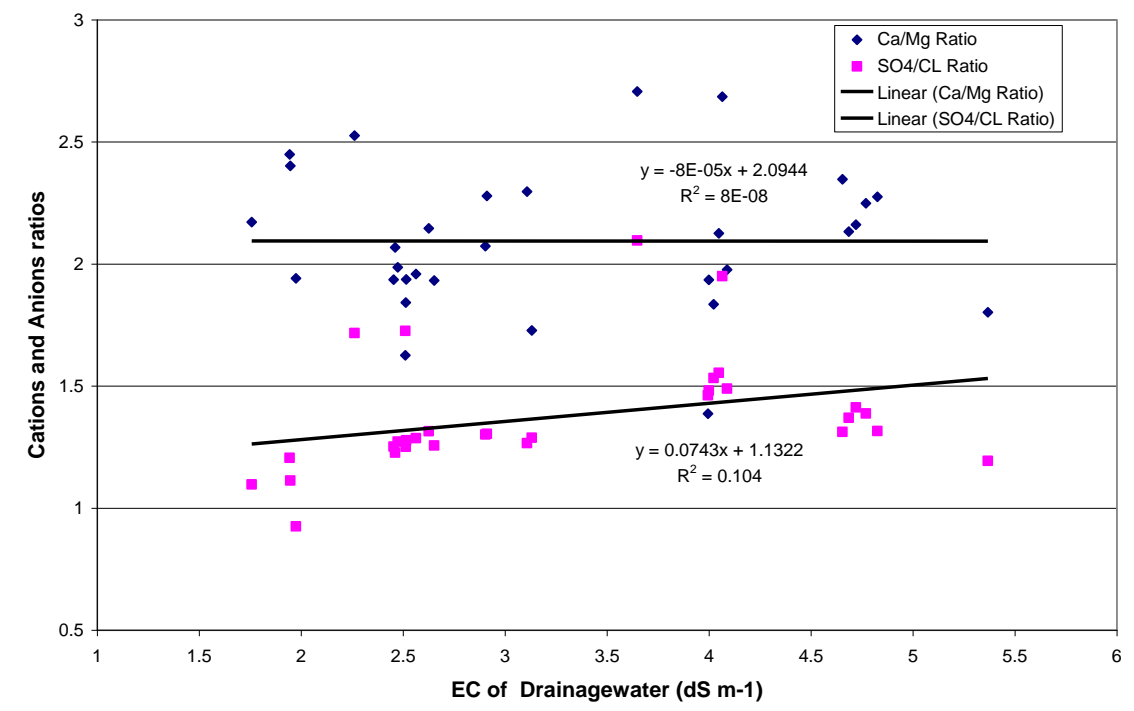

Fig.7. Relationship of EC and Cations/Anions ratios of Drainagewater of Riyadh

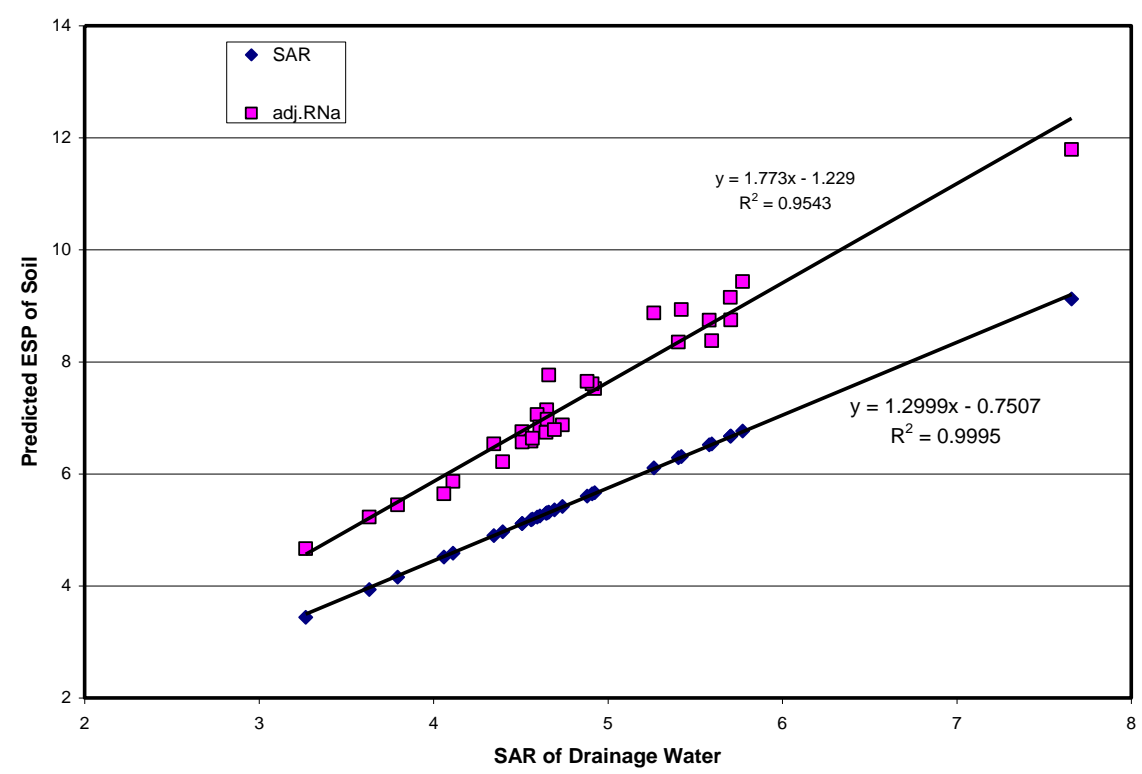

Fig.8. Predicted ESP of Soil from SAR's of Drainage Water of Riyadh 


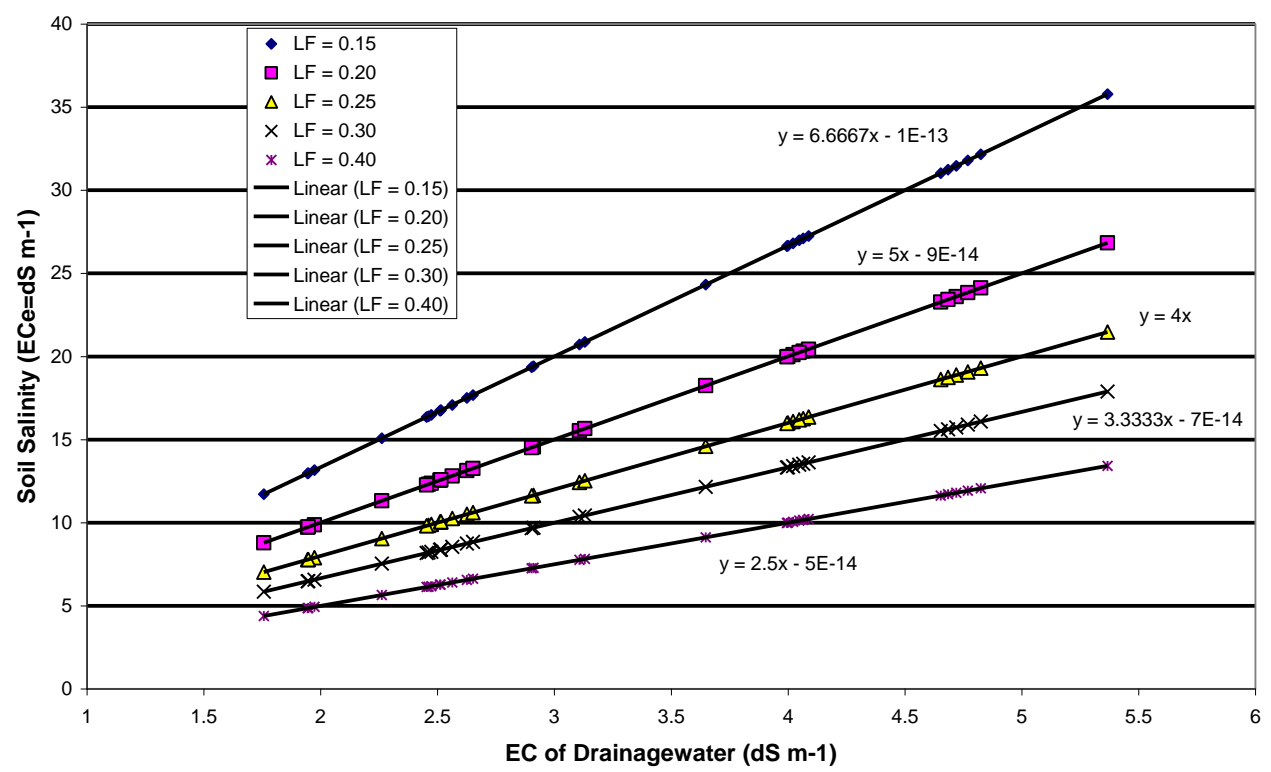

Fig. 9. Predicted Soil Salinity (ECe) from Drainagewater Salinity against Hypothetical Leaching Fractions

الملخص العربي

\section{تقييم نوعية مياه الصرف لأعادة استخدامها في اغراض الري في منطقة الرياض الري الرئ

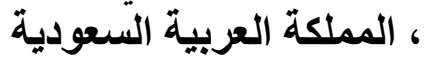 \\ د. أحمد بن عبدالرحمن العثمان}

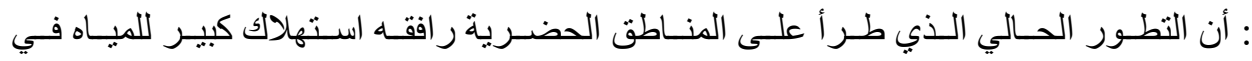

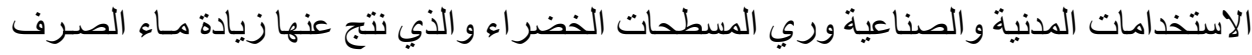

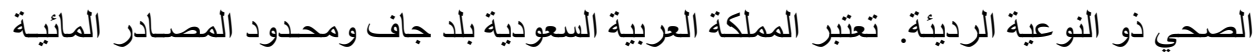

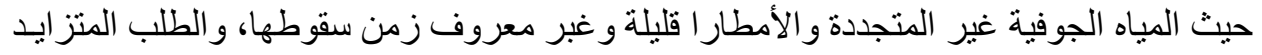

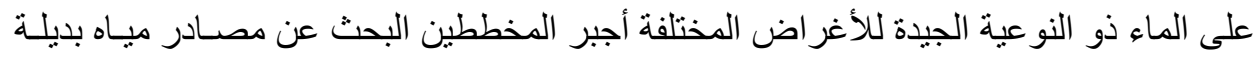

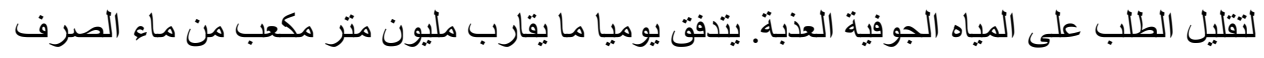

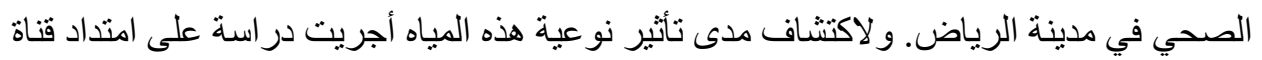

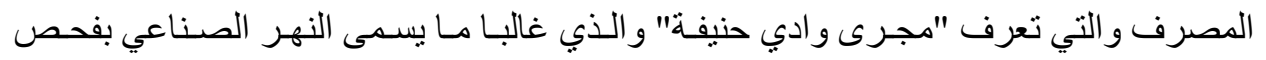

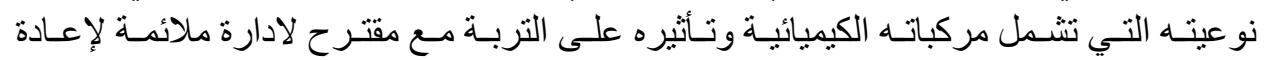

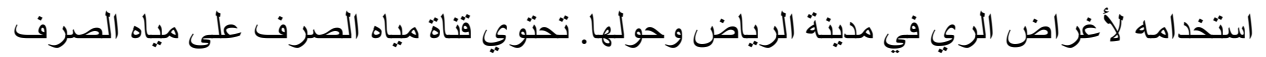

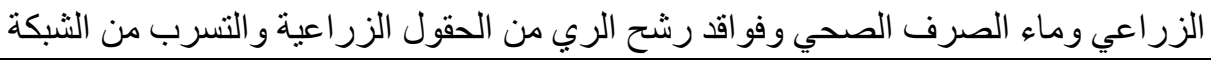

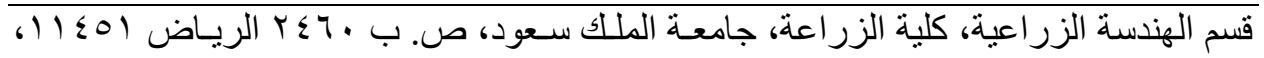
المملكة العربية السعودية. البريد الالكتروني: othmana@ksu.edu.sa 


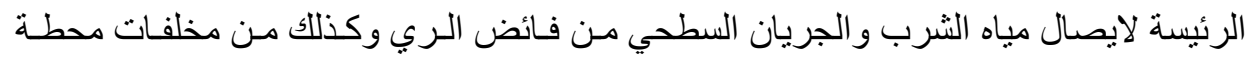

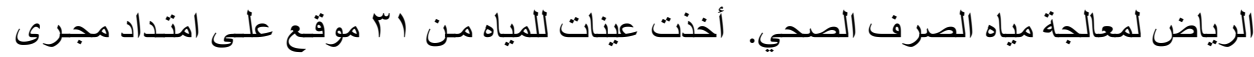

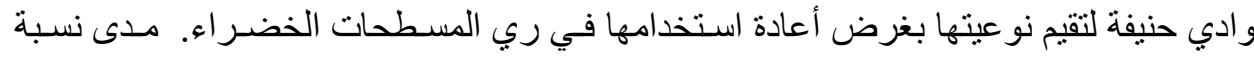

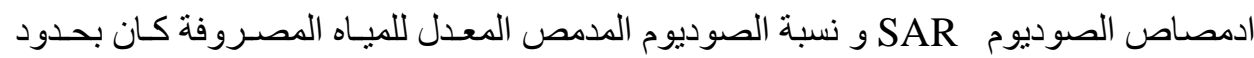

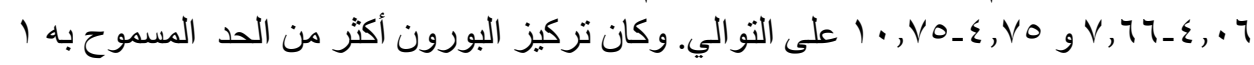

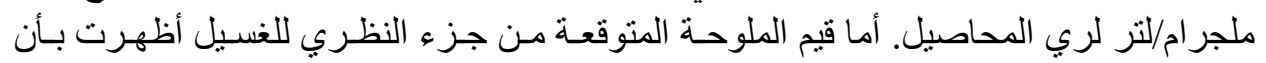

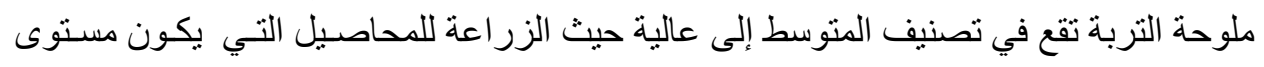

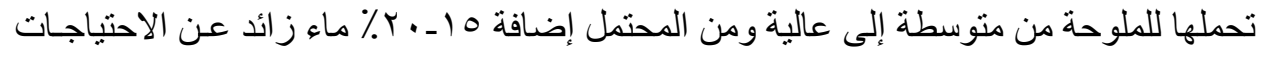

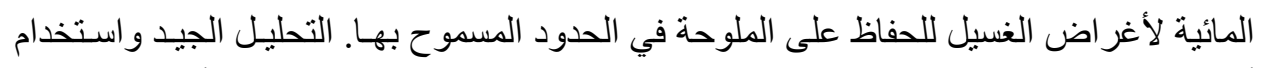

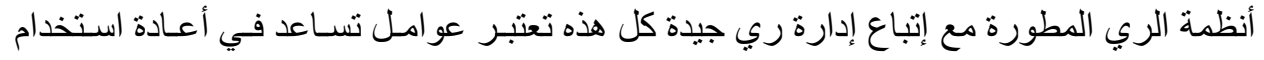

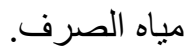

